\title{
AGGREGATION OF A FOLATE-BINDING PROTEIN FROM COW'S MILK
}

\author{
by \\ TORBEN GRAVES PEDERSEN and IB SVENDSEN \\ Department of Chemistry, Carlsberg Laboratory, \\ Gamle Carlsberg Vej 10, DK 2500 Copenhagen Valby \\ and \\ STEEN INGEMANN HANSEN, JAN HOLM and JØRGEN LYNGBYE \\ Department of Clinical Chemistry, Research Division \\ Central Hospital, Helsevej 2, DK 3400 Hillerød
}

Keywords: Ultracentrifugation, association, dissociation

\begin{abstract}
Sedimentation equilibrium experiments of folate-binding protein from cow's milk performed in the analytical ultracentrifuge at $\mathrm{pH} 5.0$ showed a single molecular species with a molecular weight of 30,000 . In contrast, at pH 7.4 sedimentation equilibrium indicated molecular weights ranging from about 30,000 to at least 300,000 . Sedimentation velocity experiments at pH 5.0 showed a single symmetrical peak with $\mathrm{s}_{20, \mathrm{w}}=2.8 \mathrm{~S}$ in agreement with a molecular weight of about 30,000 . At pH 6.0 was seen a faster moving boundary $\left(s_{20, w} \sim 6 \mathrm{~S}\right)$ in addition to the slow one. At higher $\mathrm{pH}$ two peak maxima were seen: a slow one with sedimentation coefficients of about $5 \mathrm{~S}$ and a fast one increasing from $9 \mathrm{~S}$ to $11 \mathrm{~S}$ with increasing $\mathrm{pH}$. Addition of folate further increased the sedimentation rates. By assuming that GILBERT's rapid monomer-n-mer equilibrium theory was valid also for a lower polymer in equilibrium with a higher polymer our data can be interpreted as an equilibrium between a tetramer and a polymer consisting of more than 16 monomers. In the case of folate addition the results may similarly be interpreted as an equilibrium between an octamer and a polymer composed of more than 32 monomers.
\end{abstract}

\section{INTRODUCTION}

In a previous report (12) the isolation of a folate-binding protein (FBP) from cow's milk and some of its properties were described. The molecular weight was found to be 30,000 at $\mathrm{pH}$
5.0. However, studies of the binding of folate to FBP at physiological $\mathrm{pH}(7.4)$ indicated aggregation of the protein at this $\mathrm{pH}(6,7)$. In order to obtain further evidence for the nature of this aggregation a series of studies were conducted in

Abbreviations: FBP: folate-binding protein. 
the analytical ultracentrifuge in which $\mathrm{pH}$ and the concentrations of FBP and folate were varied.

The present report confirms that extensive aggregation of the FBP takes place and that the presence of folate enhances this aggregation.

\section{MATERIALS AND METHODS}

FBP from cow's milk was prepared according to a previously published method (12) and used in the experiments in concentrations from 0.5 to 10 $\mathrm{mg} \cdot \mathrm{ml}^{-1}$. Sedimentation coefficients were determined at $20^{\circ} \mathrm{C}$ in a Spinco Model E ultracentrifuge at $59,780 \mathrm{rev} \cdot \mathrm{min}^{-1}$ using schlieren optics. The velocities of the boundaries were determined by measuring the position of the schlieren curve maxima. Molecular weights were determined by sedimentation equilibrium experiments, performed with interference optics at $20,410 \mathrm{rev} \cdot \mathrm{min}^{-1}$ using the long column meniscus depletion method described by ChervenCA (1). One series of experiments were performed in $0.2 \mathrm{M}-\mathrm{Na}$ acetate buffers at $\mathrm{pH}$ from 3.5 to 7.9 . Since the capacities of the buffers above $\mathrm{pH} 6$ were very low, $\mathrm{pH}$ was measured both before and after the experiments and found to change less than 0.1 units. Some experiments were performed in a $\mathrm{NaCl}$-phosphate buffer $\mathrm{pH} 7.4$, with ionic strength 0.2 . In the acetate buffer at $\mathrm{pH} 3.5$ was similarly added $\mathrm{NaCl}$ to an ionic strength of 0.2 to prevent a retardation of the protein due to formation of a potential gradient equivalent to an externally applied electric field (10).

\section{RESULTS}

The molecular weight of FBP at pH 5.0 was determined by a sedimentation equilibrium experiment. The slope of the plot $\ln f$ versus $x^{2}$ (see Figure 1) showed a linear dependence indicating the absence of concentration dependent aggregation at $\mathrm{pH}$ 5.0. A molecular weight of $30,000 \pm 2,000$ was calculated. using a partial specific volume of $0.71 \mathrm{ml} \cdot \mathrm{g}^{-1}$ estimated from the relative amino acid composition and a carbohydrate content of $3 \mathrm{wt} . \%$ (12).

In contrast, a sedimentation equilibrium experiment performed at $\mathrm{pH} 7.4$, as used in the folate-binding experiments $(6,7)$, showed aggregation as reflected in an upward concavity of the

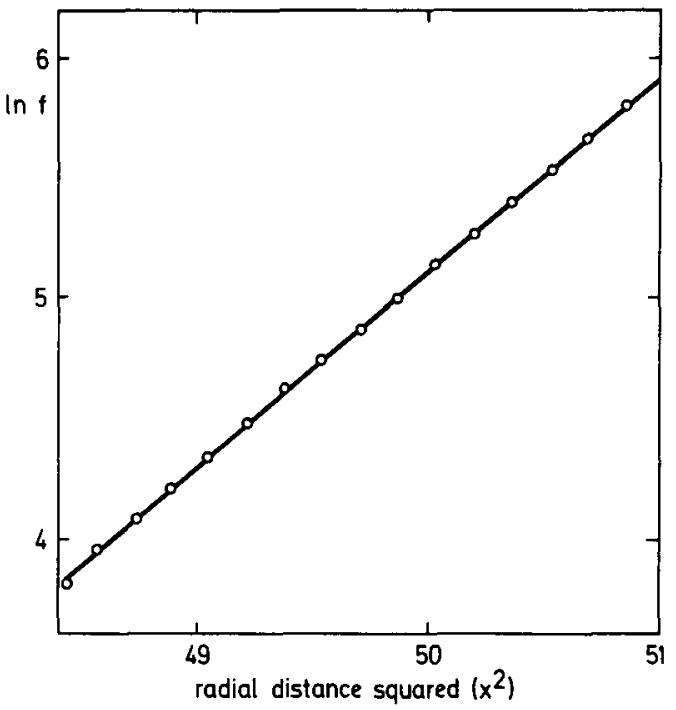

Figure 1. Plot of $\ln f$ versus $x^{2}$.

Sedimentation equilibrium ultracentrifugation of FBP at $20^{\circ} \mathrm{C}$ and at pH 5.0. The slope, $\frac{\mathrm{dln} f}{d^{2}}$, of the line is proportional to the molecular weight, $\mathrm{M}_{\mathrm{w}}=$ $\frac{2 R T d \ln f}{\left(1-\bar{v}_{Q}\right) \omega^{2}} d x^{2}$, where $R$ is the gas constant, $T$ the absolute temperature, $\omega$ the angular velocity, $\varrho$ the density of the solution, and $f$ an expression for the protein concentration at a certain distance $x$ from the center of rotation $(10)$.

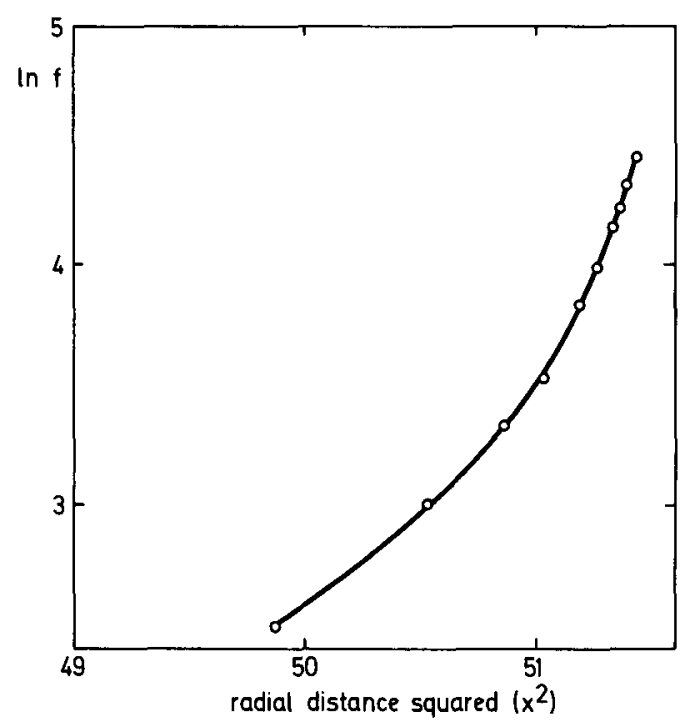

Figure 2. Plot of $\ln f$ versus $x^{2}$.

Sedimentation equilibrium ultracentrifugation of FBP at $20^{\circ} \mathrm{C}$ and at $\mathrm{pH} 7.4$. 

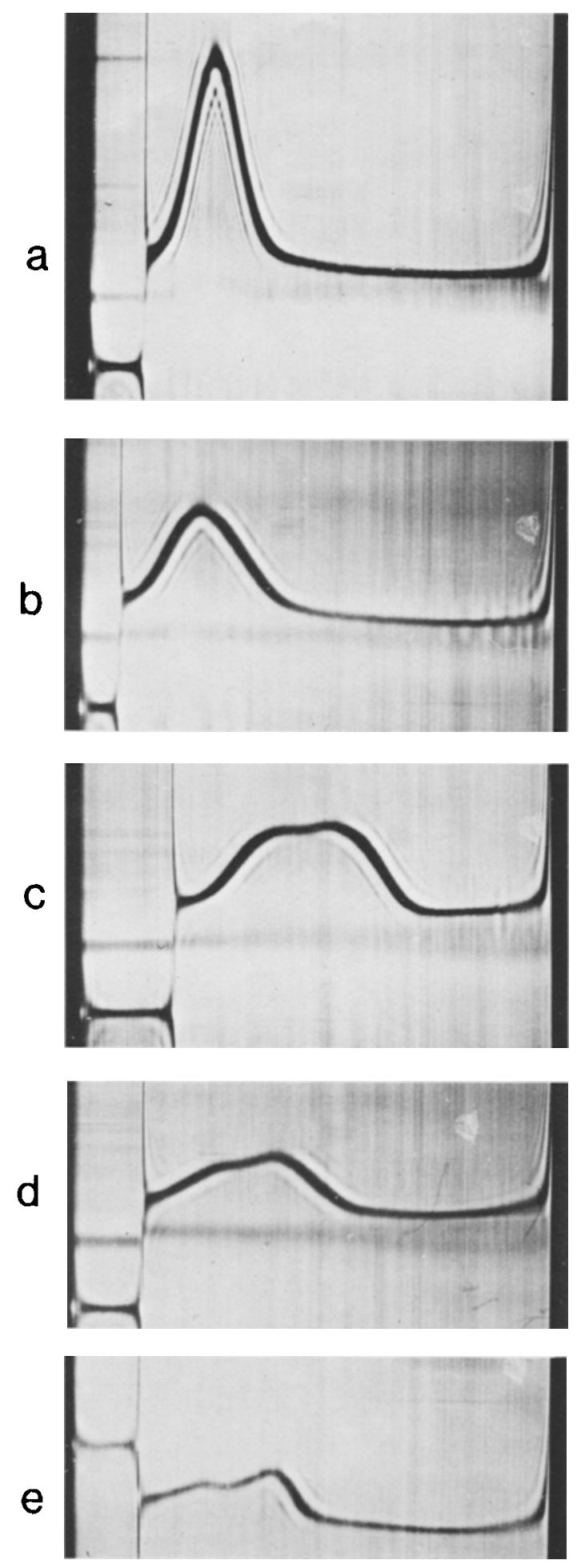

Figure 3. Sedimentation velocity experiments of $\mathrm{FBP}$. a) $\mathrm{pH} 5.0,48 \mathrm{~min}$ after start, $10.3 \mathrm{mg} \cdot \mathrm{ml}^{-1}$. b) $\mathrm{pH}$ $5.75,48 \mathrm{~min}$ after start, $8.0 \mathrm{mg} \cdot \mathrm{ml}^{-1}$. c) pH $6.0,48$ min after start, $10.1 \mathrm{mg} \cdot \mathrm{ml}^{-1}$. d) $\mathrm{pH} 6.5,26 \mathrm{~min}$ after start, $6.8 \mathrm{mg} \cdot \mathrm{ml}^{-1}$. e) $\mathrm{pH} 6.7$ with addition of folate, $19 \mathrm{~min}$ after start, $3.6 \mathrm{mg} \cdot \mathrm{ml}^{-1}$. Sedimentation is to the right in these pictures.

plot $\ln f$ versus $x^{2}$ (Figure 2). The slope obtained at the top section and the bottom section of the cell corresponded to apparent molecular weights of about 30,000 and 300,000 , respectively.

In sedimentation velocity experiments symmetrical peaks were observed at $\mathrm{pH} 3.5$ and 5.0 (Figure 3a). Between the pH-values 5.0 and 6.0 the sedimentation velocity was slightly increased with a broadening of the peaks indicating the beginning of an aggregation (Figure $3 \mathrm{~b}$ ). At $\mathrm{pH}$ above 6.0 the peaks broadened further and showed two distinct maxima (Figures $3 \mathrm{c}$ and $3 \mathrm{~d}$ ). Addition of folate increased the sedimentation velocity of both the slow and the fast peaks (Figure $3 \mathrm{e}$ ). It was also observed that the concentration of the fastest moving boundary increased both with increasing $\mathrm{pH}$ and with folate addition. At low protein concentrations and when the equilibrium was displaced to the extremes it was only possible to determine the velocity of one boundary although a shoulder on the main peak was seen.

Sedimentation coefficients as determined from the individual peaks in a large number of experiments are listed in Table I. At pH 5.0 extrapolation to infinite dilution indicated $s_{20, w}^{\circ}$ $=2.8 \mathrm{~S}$ (Figure 4). The sedimentation coefficient decreased as a function of increasing protein conentration with a slope of $0.015 \mathrm{~S}$ per $\mathrm{mg} \cdot \mathrm{ml}^{-1}$, viz. within the range expected for globular protein molecules. A sedimentation coefficient obtained at $\mathrm{pH} 3.5$ coincided with the $\mathrm{pH} 5.0$ curve indicating that no drastic unfolding or denaturation took place.

In Figure 5 it is attempted to illustrate the influence of $\mathrm{pH}$ on the sedimentation velocity. Without folate and at a protein concentration between 7 and $8 \mathrm{mg} \cdot \mathrm{ml}^{-1}$ the sedimentation velocity increased only slightly between $\mathrm{pH} 5.0$ and 6.0. At $\mathrm{pH} 6.0$ two maxima were present which travelled with velocities of $3.2 \mathrm{~S}$ and $6.3 \mathrm{~S}$, 
Tabel I

Sedimentation coefficients, s20,w, of FBP in $0.2 \mathrm{M}-$ Na-acetate buffers.

\begin{tabular}{lrlr}
\hline pH & $\begin{array}{r}\text { FBP- } \\
\text { conc }\end{array}$ & slow & s20.w \\
\hline (a) & & & \\
$\left.3.5^{*}\right)$ & 7.1 & 2.72 & \\
5.0 & 3.7 & 2.77 & \\
- & 7.1 & 2.73 & \\
- & 10.3 & 2.68 & \\
5.5 & 8.0 & 2.8 & \\
5.75 & 7.7 & 3.4 & \\
- & 8.0 & 3.3 & \\
6.0 & 3.9 & 3.4 & \\
- & 7.1 & 3.2 & 6.3 \\
- & 10.1 & 2.6 & 6.0 \\
6.5 & 6.8 & 5.1 & 9.0 \\
7.4 & 1.2 & & 10.0 \\
- & 1.9 & & 10.4 \\
$-* *)$ & 1.1 & & 9.0 \\
$-* *)$ & 2.3 & & 10.2 \\
$-* *)$ & 4.5 & & 12.3 \\
7.9 & 5.7 & 4.9 & 10.7 \\
& & & \\
(b) & & & \\
5.0 & 1.5 & 3.0 & \\
- & 3.1 & 3.55 & \\
6.0 & 3.1 & 7.5 & 10.1 \\
- & 3.2 & 7.2 & 10.2 \\
- & 3.9 & & 10.0 \\
6.7 & 3.1 & 6.9 & 11.9 \\
- & 3.6 & 7.0 & 12.7 \\
7.4 & 1.2 & & 11.7 \\
- & 1.9 & & 13.8 \\
- & 3.7 & & 15.7 \\
$\left.-*^{* *}\right)$ & 0.6 & & 10.6 \\
$\left.-{ }^{* *}\right)$ & 0.9 & & 12.4 \\
\hline
\end{tabular}

*) $\mathrm{NaCl}$ added to ionic strength $0.2 .{ }^{*}$ ) $\mathrm{NaCl}$-phosphate buffer with ionic strength 0.2 . (a) Folate free. (b) With folate in concentrations between 5 and 10 fold the numbers of FBP molecules.

respectively. At the $\mathrm{pH}$-values 6.5 and 7.9 the velocities were further increased, with sedimentation coefficients for the fast boundary increasing from $9.0 \mathrm{~S}$ to $10.7 \mathrm{~S}$, while the slow boundary appeared to reach a constant value of about $5 \mathrm{~S}$. In experiments with addition of folate a precipitate was formed at protein concentrations of 7 to $8 \mathrm{mg} \cdot \mathrm{ml}^{-1}$. However, when the concentration was decreased to less than 4 $\mathrm{mg} \cdot \mathrm{ml}^{-1} \mathrm{FBP}$ remained dissolved and sedimenta-

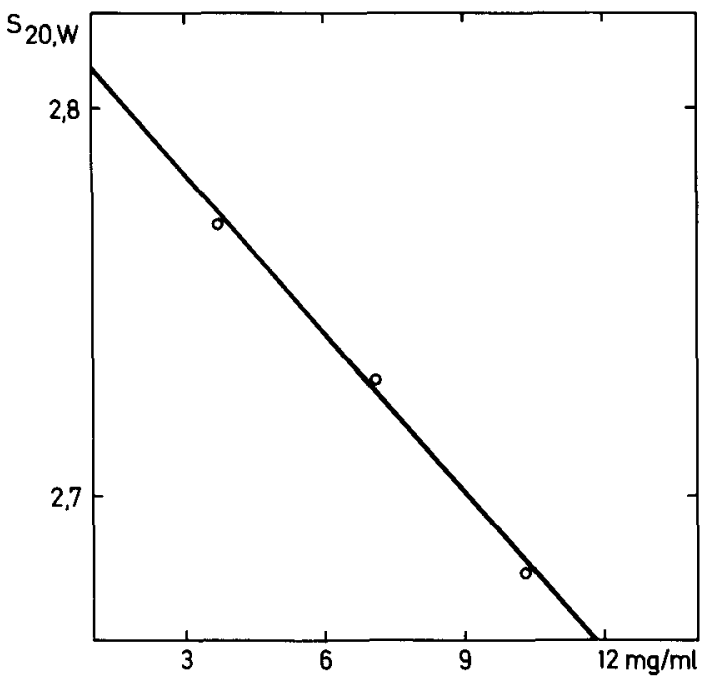

Figure 4. Sedimentation coefficients, $\mathrm{s}_{20, \mathrm{w}}$, at $\mathrm{pH} 5.0$ as a function of protein concentration.

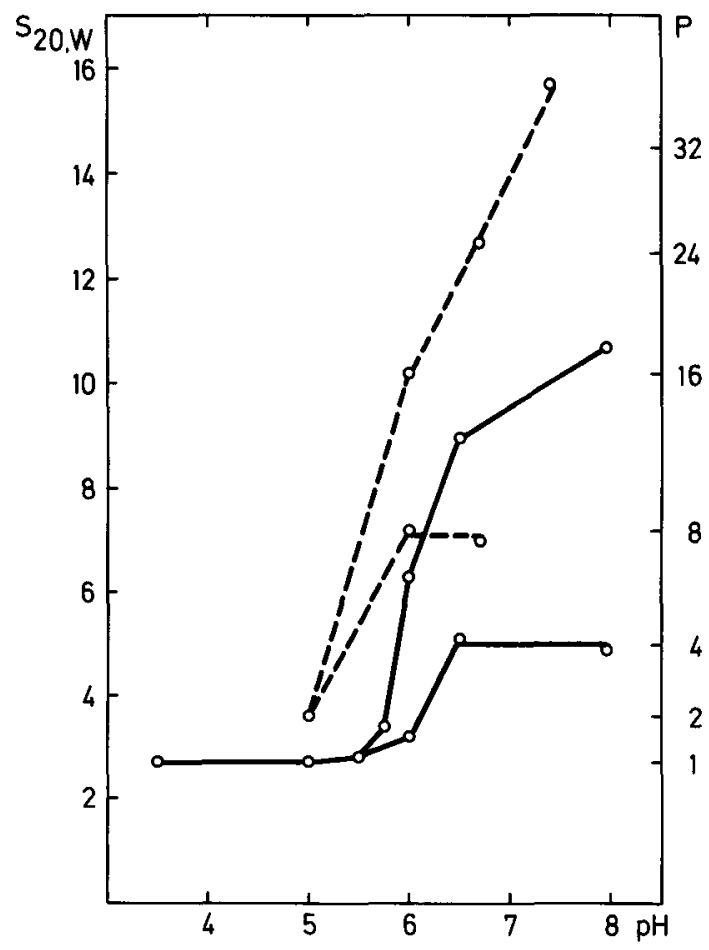

Figure 5. Sedimentation coefficients, $\mathrm{s}_{20, \mathrm{w}}$, as a function of $\mathrm{pH}$.

$P$ is the degree of polymerization expected for a pure polymer sedimenting with the $\mathbf{s}_{20}, \mathrm{w}$-values of the ordinate. - FBP without folate, the protein concentration was from 7 to $8 \mathrm{mg} \cdot \mathrm{ml}^{-1}$. - - - FBP with folate added, the protein concentrations was from 3 to $4 \mathrm{mg} \cdot \mathrm{ml}^{-1}$. Two boundaries are seen above $\mathrm{pH} 5.0$, with folate, and above $\mathrm{pH} 6.0$, without folate. 
tion experiments could be performed. The sedimentation of the complex as a function of $\mathrm{pH}$ showed the same pattern with folate as without except that all velocities were increased (Figure 5).

\section{DISCUSSION}

The understanding of the behaviour of aggregating protein systems during sedimentation experiments originate from two papers by GILBERT $(4,5)$. He studied in model systems the behavior of rapid monomer-n-mer reactions. He had to apply several restrictive assumptions such as diffusion-free sedimentation, absence of concentration dependence of sedimentation rates and a uniform centrifugal field. The essential features he found for the aggregating systems were: (a) Monomer-dimer systems will exhibit concentration gradient curves with only a single maximum, although the curve may be asymmetric. The position of this maximum will correspond, neither to the sedimentation coefficient of the dimer nor to that of the monomer, but will lie between them, approaching one or the other as the equilibrium is shifted to either side. (b) Monomer-n-mer systems $(n>2)$ may exhibit two maxima in their concentration gradients. One of these will travel with the velocity of the monomer while the other travels with a velocity intermediate between that of monomer and $n$ mer.

Assuming that FBP undergoes a rapid association-dissociation reaction we have attempted to interpret our data according to GILBERT's monomer-n-mer theory. At $\mathrm{pH}$ above 6.0 and at a protein concentration from 7 to $8 \mathrm{mg} \cdot \mathrm{ml}^{-1}$ the constant sedimentation velocity of the slow boundary was significantly higher than the sedimentation velocity observed for the monomer at $\mathrm{pH}$ values below 5.0. Presuming the slow peak to represent a globular protein complex we have tentatively assumed that the slow form might be a tetramer since the s-value of such a polymer would agree with the observed sedimentation coefficient. The size of the high polymer in equilibrium with this tetramer is reflected in the increased sedimentation velocity of the fast boundary but from sedimentation velocity experiments it is not possible to accurately determine the size.
However, a crude estimate may be obtained by using an extention of GILBERT's theory by Fusita (3) which include the effect of a sectorshaped cell in a centrifugal field. This estimate showed that the sedimentation coefficient for the high polymer form in equilibrium with the tetramer would correspond to a polymer consisting of 20 to 26 monomer units if it was of globular shape. In the case of folate addition, at concentrations from 3 to $4 \mathrm{mg} \cdot \mathrm{ml}^{-1}$ and above $\mathrm{pH} 5.5$, the same kind of consideration would suggest an octameric form to be in equilibrium with a polymer composed of more than 32 monomers.

This crude estimate of the size of the high polymer forms is consistent with the sedimentation equilibrium experiment at $\mathrm{pH} 7.4$ which produced a protein concentration at the bottom section of the cell of 3 to $4 \mathrm{mg} \cdot \mathrm{ml}^{-1}$ and showed an apparent molecular weight of about 300,000 indicating a degree of polymerization of $n \geqq 10$. Since the aggregation is a function of the protein concentration (e.g. the in $\mathrm{f}$ versus $\mathrm{x}^{2}$ slope in the same experiment at very low concentration correspond to a monomer) it is likely that the polymerization at a concentration from 7 to 8 $\mathrm{mg} \cdot \mathrm{ml}^{-1}$ would be as found in the sedimentation velocity experiments, viz. $\mathrm{n}>16$ (Figure 5).

That FBP molecules aggregate has previously been shown by more indirect methods such as gel filtration and studies of the binding of folate. Thus, SALTER et al. (9) showed that the molecular weight of FBP was concentration dependent when determined at $\mathrm{pH} 7.4$ by gel filtration on Sephadex G-100. This finding was interpreted as aggregation taking place with increasing FBP concentration.

In the present paper the value of 30,000 determined in the analytical ultracentrifuge was obtained at $\mathrm{pH} 5$ where the molecule is in a monomeric state while molecular weights of $35,000(6,9)$ for the cow's FBP and $39,000(8)$ for FBP from goat were obtained at $\mathrm{pH} 7.3-7.4$ by gel filtration. In these cases probably a monomer (dominating species) is in a rapid equilibrium with polymers resulting in a slight elevation of the molecular weight.

Equilibrium dialysis studies of the binding of folate to FBP at $\mathrm{pH} 7.4$ displayed positive cooperativity which could be explained assuming a concomitant aggregation to polymers (7). 
The present study using the analytical ultracentrifuge confirms the aggregation of FBP molecules. This aggregation is enhanced upon binding of folate and is strongly $\mathrm{pH}$-dependent with a great change around $\mathrm{pH} 6$.

\section{ACKNOWLEDGEMENTS}

We are indepted to professor M. OTTESEN for stimulating discussions and critical review of the manuscript. LizZi AUGUSTSEN is gratefully acknowledged for drawing the figures.

\section{REFERENCES}

1. Chervenca, C: H.: Long column meniscus depletion sedimentation equilibrium technique for the analytical centrifuge. Anal. Biochem. 34, 24-29 (1970)

2. Elias, H.-G.: Ultracentrifugen-Methoden, Beckman Instruments $\mathrm{GmbH}$, München, p 186 (1961)

3. FuJita, H.: "The mathematical theory of sedimentation analysis«. Academic press, New York (1962)

4. GilberT, G. A.: Sedimentation and electrophoresis of interacting substances I. Idealized boundary shape for a single substance aggregating reversibly. Proc. Roy. Soc. Ser. A 250, 377-388 (1959)
5. GILBerT, G. A.: Sedimentation and electrophoresis of interacting substances III. Sedimentation of a reversibly aggregating substance with concentration dependent sedimentation coefficients. Proc. Roy. Soc. Ser. a 276, 354-366 (1963)

6. Hansen, S. I., J. Holm \& J. Lyngbye: Cooperative binding of folate to a protein isolated from cow's whey. Biochim. Biophys. Acta 535, 309318 (1978)

7. Hansen, S. I., J. Holm \& J. Lyngbye: Folate binding to a polymerizing system (octameric) in milk. Abstr. 12th FEBS meeting Dresden 1978

8. Rubinoff, M., C. Schreiber \& S. Waxman: The isolation and characterization of the folate binding protein from goat milk. FEBS Letters 75, 244-248 (1977)

9. Salter, D. N., J. E. Ford, K. J. Scott \& P. ANDREWS: Isolation of the folate binding protein from cow's milk by the use of affinity chromatography. FEBS Letters 20, 302-306 (1972)

10. Schachman, H. K. S.: Ultracentrifugation in Biochemistry, Academic Press, p 225 (1959)

11. Svedberg, T. \& K. O. Pedersen: The ultracentrifuge, Oxford, At the Claredon Press, p 8 (1940)

12. Svendsen, I., B. Martin, T. G. Pedersen, S. I. HANSEN, J. Holm \& J. LyNGBYE: Isolation and characterization of the folate-binding protein from cow's milk. Carlsberg Res. Commun. 44, 89-99 (1979) 